\title{
Effect of seed rate and irrigation level on the performance of wheat cv. Gourab
}

\author{
N. A. M. E. Kabir, A. R. Khan, M. A. Islam and M. R. Haque ${ }^{1}$ \\ Department of Agronomy, Bangladesh Agricultural University, Mymensingh-2202, Bangladesh \\ ${ }^{1}$ Bangladesh Institute of Nuclear Agriculture (BINA), Mymensingh-2200, Bangladesh
}

\begin{abstract}
The effect of seed rate and irrigation level on the performance of wheat cv. Gourab was studied. The experiment comprises of two factors namely (1) four seed rate viz. 100,120, 140 and $160 \mathrm{kgha}^{-1}$ and (2) four levels of irrigation namely (i) no irrigation i.e. control, (ii) one irrigation given at Crown root initiation (CRI) stage, (iii) two irrigations given at $\mathrm{CRI}$ and Panicle initiation stages and (iv) three irrigation given at CRI, panicle initiation and grain filling stages. All of the yields contributing characters were significantly affected by seed rate except $1000-$ grain weight. The highest plant height $(82.36 \mathrm{~cm})$, total tillers plant ${ }^{-1}(8.99)$, effective tillers plant ${ }^{-1}(3.49)$, spike $^{-1}$ length $(8.05 \mathrm{~cm})$, spikelets spike ${ }^{-1}(15.50)$, filled grain spike ${ }^{-1}(31.05)$, grain yield $\left(2.82 \mathrm{t} \mathrm{ha}^{-1}\right)$, straw yield $(3.73 \mathrm{t}$ $\left.\mathrm{ha}^{-1}\right)$, biological yield $\left(6.55 \mathrm{t} \mathrm{ha}^{-1}\right.$ ) and harvest index (42.43\%) were recorded from the seed rate of $140 \mathrm{~kg} \mathrm{ha}^{-1}$. Most of the yields contributing characters were significant due to effect of irrigation level. The highest plant height $(82.33 \mathrm{~cm})$, spike length $(8.37 \mathrm{~cm})$, filled grain spike ${ }^{-1}(31.90)$, effective tillers plant ${ }^{-1}(3.31)$, grain yield (3.30 $\mathrm{t} \mathrm{ha}^{-}$ $\left.{ }^{1}\right)$, straw yield $\left(4.09 \mathrm{t} \mathrm{ha}^{-1}\right)$, biological yield $\left(7.39 \mathrm{t} \mathrm{ha}^{-1}\right)$ and harvest index $(44.47 \%)$ were recorded when one irrigation given at CRI stage. The interaction between seed rate and irrigation level influenced significantly all the plant characters except plant height, spikelets spike ${ }^{-1}$ and 1000 -grains weight. The highest spike length (8.63 $\mathrm{cm})$, grain yield $\left(3.70 \mathrm{t} \mathrm{ha}^{-1}\right)$, biological yield $\left(8.06 \mathrm{t} \mathrm{ha}^{-1}\right)$ and harvest index $(45.91 \%)$ were found from the seed rate of $140 \mathrm{~kg} \mathrm{ha}^{-1}$ combined with one irrigation applied at CRI stage. So it may be stated that the seed rate of $140 \mathrm{~kg} \mathrm{ha}^{-1}$ with one irrigation given at CRI stage may be practiced for better performance of wheat cv. Gourab.
\end{abstract}

Keyword: Seed rate, Irrigation level, Gourab

\section{Introduction}

Wheat is grown in rabi season in Bangladesh when maximum land is occupied by boro rice. The water requirement for boro rice is much higher than that of wheat. The water requirement of wheat is only $25-33 \%$ of boro rice (BARI, 1990). The production cost of wheat is also less than that of boro rice. Therefore, wheat has much potentiality to replace boro rice in Bangladesh in terms of its economic production and nutritional quality. In rabi season, most of the land, especially in NorthWestern part of the country remains fallow due to lack of irrigation facilities which could easily be brought under wheat cultivation. The climate and soil of Bangladesh are quite favorable for the cultivation of wheat during this period. Wheat yield in farmers field is very low i.e. only $2 \mathrm{t} \mathrm{ha}^{-1}$ but in the research stations it is about $4 \mathrm{t} \mathrm{ha}^{-1}$ (BARI, 1990). This might be due to the use of improper production technology by the farmers. To get maximum yield it is necessary to use quality seed and improved agronomic techniques such as optimum seed rate, time of seeding, irrigation, fertilizer application, weeding, water management, time of harvest etc. There is a need to increase the yield of wheat per unit area in Bangladesh to provide the ever-increasing food requirement of the country, as the cultivable area is very limited and there is little scope to expand the area for production of wheat.

Seed rate plays a vital role for optimum plant densities which is a pre-requisite for increased seed yield. It influences the yield and yield attributes of wheat (Singh and Singh, 1987). Seed rate depends on seeding method. The broadcasting method requires more seeds than line sowing. Higher seed rate produces more plants in unit area resulting in less intra-crop competition hereby affecting the yield and production cost. On the other hand, lower seed rate may reduce the yield drastically.

In Bangladesh, wheat ranks second position in respect of total area of land having an annual production of 0.976 million tons and total area of 0.56 million hectares (BBS, 2005). Irrigation at optimum level is one of the most important tools for boosting up the yield of wheat (Razzaque et al., 1992). It influences dry matter production, plant height, leaf area, duration of grain filling and grain protein content of wheat (Thomson and chase 1992). In Bangladesh, the rainfall during rabi season is 
characteristically scanty and uncertain. As such, wheat gives poor yield under non-irrigated condition. Moreover irrigation facilities are not so extensive to ensure abundant irrigation water throughout the country. Insufficient water affects the germination of seed and uptake of nutrients from soil. Nutrients from soil reach the root surface by mass flow and diffusion process which are related to moisture content of the soil. Moreover movement of nutrients through the plant body by physiological activities is also associated with soil water (Tisdale et al., 1985). But as a matter of fact, irrigation water in Bangladesh is a limited resources and hence irrigation practices must be rationalized if irrigation is provided at critical growth stages of wheat. Because the yield of wheat is influenced by the level of irrigation as well as stages of crop growth and development at which irrigation are given. Therefore, when water supply is limited, it is necessary to take of the critical stages of crop growth into account with respect to soil moisture level. In view of the above circumstances, the present study was undertaken to find out the optimum seed rate and irrigation level for wheat cv. Gourab; and to study the interaction effect between seed rate and irrigation level on the yield of wheat cv. Gourab.

\section{Materials and Methods}

An experiment was conducted at the Agronomy Field Laboratory, Bangladesh Agricultural University, Mymensingh during the period from November 2005 to April 2006. The experimental land was medium high belonging to the non-calcareous dark grey flood soil having silty loam texture. It belongs to the agro-ecological zone of Old Brahmaputra Flood Plain (AEZ-9). Wheat variety Gourab (BARI GAM 20) was used as planting material. It is a high yielding variety and suits better as a late variety. Sowing time and plant height range from 15 November to 7 December and 90 to $102 \mathrm{~cm}$ producing 56 tillers per plant. The spike length varieties between $9-10 \mathrm{~cm}$ and seeds spike ${ }^{-1}$ are $45-50$ containing white seed color. Gourab matures within 100-108 days and yield varies between 3.6-4.5 ton ha ${ }^{-1}$. The cultivar is claimed to be restraint to leaf rust and leaf spot (BARI, 2000). Treatments included in the experiment were as follows: Seed rate $\left(\mathrm{kg} \mathrm{ha}^{-1}\right)$ viz. $100\left(\mathrm{~S}_{1}\right), 120\left(\mathrm{~S}_{2}\right), 140\left(\mathrm{~S}_{3}\right), 160\left(\mathrm{~S}_{4}\right)$ and irrigation level viz. no irrigation i.e. control $\left(\mathrm{I}_{0}\right)$, one irrigation given at Crown Root Initiation (CRI) stage $\left(\mathrm{I}_{1}\right)$, two irrigation given at $\mathrm{CRI}$ and panicle initiation stages $\left(\mathrm{I}_{2}\right)$, three irrigation given at CRI panicle initiation and grain filling stages $\left(I_{3}\right)$. The experiment was laid out in a split-plot design with three replication in which level of irrigation was assigned in the main plot and seed rate in the sub plot at random. The experimental field was finally prepared by a country plough followed by laddering for breaking clods and leveling the land. All weeds, stubbles and crop residues of the field were removed prior to sowing of seeds and whole experimental area was divided into unit plots maintaining the desired spacing. The field was fertilized with urea, triple super phosphate, muriate of potash, gypsum @ 220, 180, 50, $120 \mathrm{~kg} \mathrm{ha}^{-1}$ respectively. Two-third of urea, the whole amount of triple super phosphate, muriate of potash, gypsum was applied at the time of final land preparation. The rest urea was top dressed at CRI stage. Seeds were sown by hand at depth of $4-5 \mathrm{~cm}$ a part furrows with a tine made of iron. After sowing, the seeds were covered with soil. Care was taken to avoid damage of the seeds and emerging seedlings by birds. Intercultural operations such as weeding(two weeding one at 25 days after sowing (DAS) and the other at 50 DAS were done by the help of a nirani), Irritation was given as per experimental specification. The crop was harvested at full maturity. Ten plants (excluding border plants) were selected randomly from each unit plot and uprooted before harvesting for recording data. The harvested crop of each plot was bundled separately, tagged properly and brought to the clean threshing floor. The bundles were dried sun, threshed and then grains were cleaned. The seed and straw weight for each plot were recorded after sun drying to constant weight. The dry weight of grains of sample plants was added to the respective unit plot to record the final yield $\operatorname{plot}^{-1}$. The grain and straw yield was finally converted in to $\mathrm{t} \mathrm{ha}^{-1}$. All the collected and calculated data were analyzed following the ANOVA-technique. The mean differences among the treatments were adjudged by Duncan's Multiple Range Test (Gomez and Gomez, 1984), using a computer operated program named MSTAT-C.

\section{Results and Discussion}

Effect of seed rate: All of the yields contributing characters were significantly affect due to seed rate except 1000 -grain weight. The tallest plant $(82.36 \mathrm{~cm})$ was found from the seed rate of $140 \mathrm{~kg} \mathrm{ha}^{-1}$ and the shortest plant $(77.80 \mathrm{~cm})$ was found for the seed rate of $100 \mathrm{~kg} \mathrm{ha}^{-1}$. The highest number of total tillers plant ${ }^{-1}(8.99)$, effective tillers plant ${ }^{-1}(3.49)$ was recorded from the seed rate of $140 \mathrm{~kg} \mathrm{ha}^{-1}$ 
and the lowest number of total tillers plant ${ }^{-1}$ (8.27), effective tillers plant $^{-1}$ (2.48) was found from the seed rate of $100 \mathrm{~kg} \mathrm{ha}^{-1}$. On the other hand the highest number of non-effective tillers plant ${ }^{-1}(1.17)$ was found from the seed rate of $100 \mathrm{~kg} \mathrm{ha}^{-1}$ and the lowest $(0.95)$ was recorded for the seed rate of $140 \mathrm{~kg} \mathrm{ha}^{-1}$ which is statistically similar to the seed rate of $120 \mathrm{~kg} \mathrm{ha}^{-1}$. The result is in agreement with the findings of Azimzadeh and Koocheki (1999). The longest spike $(8.05 \mathrm{~cm})$, highest number of spikelets spike ${ }^{-1}(15.50)$ was produced by the seed rate of $140 \mathrm{~kg} \mathrm{ha}^{-1}$ and the shortest spike (7.10 $\mathrm{cm}$ ), shortest number of spikelets spike ${ }^{-1}(13.85)$ was found from the seed rate of $100 \mathrm{~kg} \mathrm{ha}^{-1}$. Talukder et al., (2004) obtained similar results. The highest number of filled grains spike ${ }^{-1}$ (31.05) was recorded from the seed rate of $140 \mathrm{~kg} \mathrm{ha}^{-1}$ and the lowest (26.55) was recorded from the seed rate of $100 \mathrm{~kg} \mathrm{ha}^{-1}$. The highest number of unfilled grains spike ${ }^{-1}$ (3.51) was found for the seed rate of $100 \mathrm{~kg}$ $\mathrm{ha}^{-1}$ which was statistically similar the seed rate $160 \mathrm{~kg} \mathrm{ha}^{-1}$ and the lowest (2.82) was found from the seed rate of $140 \mathrm{~kg} \mathrm{ha}^{-1}$. Numerically the highest 1000 -grain weight $(33.48 \mathrm{~g})$ was obtained from the seed rate of $140 \mathrm{~kg} \mathrm{ha}^{-1}$. The results showed that the highest grain yield $\left(2.82 \mathrm{t} \mathrm{ha}^{-1}\right)$ was obtained by the seed rate of $140 \mathrm{~kg} \mathrm{ha}^{-1}$, because of higher total tillers plant ${ }^{-1}$, effective tillers plant ${ }^{-1}$, lower noneffective tillers plant ${ }^{-1}$, longest spike, highest number of spikelets spike ${ }^{-1}$. The lowest grain yield $(2.15 \mathrm{t}$ $\mathrm{ha}^{-1}$ ) was produced by the seed rate of $100 \mathrm{~kg} \mathrm{ha}^{-1}$. The result is in agreement with the findings of Talukder et al., (2004). The highest straw yield (3.73 $\left.\mathrm{t} \mathrm{ha}^{-1}\right)$ was found from the seed rate of $140 \mathrm{~kg}$ $\mathrm{ha}^{-1}$ and the lowest $\left(3.26 \mathrm{t} \mathrm{ha}^{-1}\right.$ ) was found for the use seed rate of $100 \mathrm{~kg} \mathrm{ha}^{-1}$ which was identical with the seed rate of $160 \mathrm{~kg} \mathrm{ha}^{-1}$. The highest harvest index (42.43\%) was obtained from the seed rate of $140 \mathrm{~kg} \mathrm{ha} \mathrm{ha}^{-1}$ and the lowest harvest index (39.12\%) was obtained from the seed rate of $100 \mathrm{~kg} \mathrm{ha}^{-1}$. It was observed that by using low amount of seed rate harvest decreased harvest index.

Effect of Irrigation level: Most of the yields contributing characters were significant due to effect of irrigation level except spikelets spike ${ }^{-1}$ and 1000 -grain weight. The tallest plant $(82.33 \mathrm{~cm})$ was obtained by one irrigation given at crown root initiation (CRI) stage and the shortest plant $(77.07 \mathrm{~cm})$ was obtained without irrigation. The highest number of total tillers plant ${ }^{-1}(9.07)$ was recorded by two irrigations given at $\mathrm{CRI}$ and panicle initiation stage which was statistically identical with one irrigation given at CRI stage and the lowest (8.18) observed when no irrigation was given. The highest effective tillers plant ${ }^{-1}$ (3.31) was obtained by one irrigation applied was at CRI stage which is statistically similar to two irrigations applied at CRI and panicle initiation stages, the lowest (2.43) was recorded when no irrigation was applied. The highest number of non-effective tillers plant $^{-1}(1.42)$ was obtained by no irrigation application and the lowest (0.61) was found in one irrigation applied at CRI stage. The longest spike length $(8.37 \mathrm{~cm})$, highest number of filled grains spike ${ }^{-1}(31.90)$ was recorded by one irrigation given at CRI stage and the shortest spike length $(6.77 \mathrm{~cm})$, lowest number of filled grains spike $^{-1}$ (26.21) was recorded when no irrigation was given. On the other hand the highest number of unfilled grains spike ${ }^{-1}$ (3.97) was found when no irrigation was applied and the lowest (2.67) was found from one irrigation applied at CRI stage. The result is in agreement with the findings of Singh and Uttam (1993). The highest grain yield $\left(3.30 \mathrm{t} \mathrm{ha}^{-1}\right)$ was produced by one irrigation applied at CRI stage and the lowest $\left(1.77 \mathrm{t} \mathrm{ha}^{-1}\right)$ was produced by control treatment which was statically similar to three irrigations applied at CRI, panicle initiation and grain filling stages. The highest straw yield (4.09 $\left.\mathrm{t} \mathrm{ha}^{-1}\right)$ was obtained by one irrigation applied at CRI stage and lowest $\left(2.99 \mathrm{t} \mathrm{ha}^{-1}\right)$ was obtained by control treatment applied which was statically similar with applied of three irrigations application at $\mathrm{CRI}$, panicle initiation and grain filling stages. The highest straw yield was observed with three irrigation. Increased straw yield with irrigation was attributed mainly due to increase in plant height and tillers plant ${ }^{-1}$. The results of grain and straw yield supported by Singh and Uttam (1993). The highest harvest index (44.67\%) was observed with one irrigation applied at CRI stage which was statistically similar to two irrigation applied at CRI and panicle initiation stages and harvest index (37.06\%) was obtained from no irrigation treatment.

Effect of interaction: The interaction between seed rate and irrigation level influenced significantly all the plant characters except plant height, spikelets spike ${ }^{-1}$ and 1000 -grains weight. 
Table1. Effect of Seed rate on the yield and yield performance of wheat cv. Gourab

\begin{tabular}{|c|c|c|c|c|c|c|c|c|c|c|c|c|c|}
\hline Seed rate $\left(\mathrm{kg} \mathrm{ha}^{-1}\right)$ & $\begin{array}{l}\text { Plant } \\
\text { height } \\
(\mathrm{cm})\end{array}$ & $\begin{array}{l}\text { Total } \\
\text { tillers } \\
\text { plant }^{-1} \\
\end{array}$ & $\begin{array}{l}\text { Effective } \\
\text { tillers plant }{ }^{-1} \\
\text { (no.) }\end{array}$ & $\begin{array}{c}\text { Non-effective } \\
\text { tillers plant }{ }^{-1} \\
\text { (no.) }\end{array}$ & $\begin{array}{l}\text { Spike } \\
\text { length } \\
(\mathrm{cm})\end{array}$ & \begin{tabular}{|c} 
Spikelets \\
spike $^{-1}$ \\
(no.) \\
\end{tabular} & $\begin{array}{l}\text { Filled grains } \\
\text { Spike } \text { e }^{-1} \\
\text { (no.) }\end{array}$ & $\begin{array}{c}\text { Unfilled } \\
\text { grains Spike } \\
\text { (no.) } \\
\end{array}$ & $\begin{array}{l}\text { 1000-grain } \\
\text { weight } \\
\text { (g) }\end{array}$ & $\begin{array}{l}\text { Grain } \\
\text { Yield } \\
\left(\mathrm{t} \mathrm{ha}^{-1}\right)\end{array}$ & $\begin{array}{l}\text { Straw } \\
\text { Yield } \\
\left(\mathrm{t} \mathrm{ha}^{-1}\right)\end{array}$ & \begin{tabular}{|l|} 
Biological \\
Yield \\
$\left(\mathrm{t} \mathrm{ha}^{-1}\right)$ \\
\end{tabular} & $\begin{array}{c}\text { Harvest } \\
\text { Index } \\
(\%) \\
\end{array}$ \\
\hline 100 & $77.80^{d}$ & $8.27^{\mathrm{b}}$ & $2.48^{d}$ & $1.17^{\mathrm{a}}$ & $7.10^{c}$ & $13.85^{\mathrm{c}}$ & $26.55^{d}$ & $3.51^{\mathrm{a}}$ & 32.91 & $2.15^{d}$ & $3.26^{c}$ & $5.41^{d}$ & $39.12^{\mathrm{C}}$ \\
\hline 120 & $80.42^{b}$ & $8.84^{\mathrm{a}}$ & $2.98^{\mathrm{b}}$ & $0.99^{\mathrm{c}}$ & $7.85^{\mathrm{ab}}$ & $14.80^{b}$ & $28.95^{\mathrm{b}}$ & $3.09^{b}$ & 32.90 & $2.57^{\mathrm{b}}$ & $3.57^{\mathrm{b}}$ & $6.14^{\mathrm{b}}$ & $41.28^{b}$ \\
\hline 140 & $82.36^{a}$ & $8.99^{a}$ & $3.49^{a}$ & $0.95^{\mathrm{C}}$ & $8.05^{a}$ & $15.50^{\mathrm{a}}$ & $31.05^{\mathrm{a}}$ & $2.82^{\mathrm{C}}$ & 33.48 & $2.82^{\mathrm{a}}$ & $3.73^{\mathrm{a}}$ & $6.55^{\mathrm{a}}$ & $42.43^{a}$ \\
\hline 160 & $79.46^{\mathrm{c}}$ & $8.76^{a}$ & $2.71^{\mathrm{C}}$ & $1.09^{\mathrm{b}}$ & $7.67^{b}$ & $14.34^{\mathrm{bc}}$ & $27.56^{\mathrm{c}}$ & $3.38^{\mathrm{a}}$ & 33.45 & $2.38^{\mathrm{C}}$ & $3.27^{\mathrm{c}}$ & $5.72^{\mathrm{c}}$ & $40.94^{b}$ \\
\hline Level of significance & ** & ** & ** & ** & ** & ** & ** & ** & NS & ** & ** & ** & ** \\
\hline $\mathrm{s} \bar{x}$ & 0.32 & 0.10 & 0.04 & 0.02 & 0.09 & 0.21 & 0.326 & 0.05 & 0.26 & 0.02 & 0.05 & 0.89 & 0.37 \\
\hline $\mathrm{CV}(\%)$ & 3.71 & 6.28 & 6.50 & 11.97 & 4.65 & 4.22 & 4.18 & 10.62 & 1.54 & 4.39 & 3.88 & 4.94 & 2.47 \\
\hline
\end{tabular}

In a column figures having common letter(s) do not differ significant as per DMRT. ${ }^{* *}$ indicates $1 \%$ level of probability, ${ }^{\text {NS }}$ indicates not significant

\section{Table 2. Effect of Irrigation on the yield and yield performance of wheat cv. Gourab}

\begin{tabular}{|c|c|c|c|c|c|c|c|c|c|c|c|c|c|}
\hline Level of Irrigation & $\begin{array}{c}\text { Plant } \\
\text { height } \\
(\mathrm{cm}) \\
\end{array}$ & $\begin{array}{l}\text { Total } \\
\text { tillers } \\
\text { plant }^{-1} \\
\end{array}$ & \begin{tabular}{|c|} 
Effective \\
tillers plant \\
(no.)
\end{tabular} & $\begin{array}{c}\text { Non-effective } \\
\text { tillers plant }{ }^{-1} \\
\text { (no.) }\end{array}$ & $\begin{array}{l}\text { Spike } \\
\text { length } \\
(\mathrm{cm}) \\
\end{array}$ & $\begin{array}{l}\text { Spikelets } \\
\text { spike }^{-1} \\
\text { (no.) }\end{array}$ & $\begin{array}{c}\text { Filled grains } \\
\text { Spike }^{-1} \\
\text { (no.) } \\
\end{array}$ & $\begin{array}{c}\text { Unfilled grains } \\
\text { Spike }^{-1} \\
\text { (no.) } \\
\end{array}$ & $\begin{array}{l}\text { 1000-grain } \\
\text { weight }(\mathrm{g})\end{array}$ & $\begin{array}{l}\text { Grain } \\
\text { Yield } \\
\left(\mathrm{t} \mathrm{ha}^{-1}\right) \\
\end{array}$ & $\begin{array}{l}\text { Straw } \\
\text { Yield } \\
\left(\mathrm{t} \mathrm{ha}^{-1}\right) \\
\end{array}$ & $\begin{array}{c}\begin{array}{c}\text { Biological } \\
\text { Yield } \\
\left(\mathrm{t} \mathrm{ha}^{-1}\right)\end{array} \\
\end{array}$ & $\begin{array}{c}\text { Harvest } \\
\text { Index } \\
(\%) \\
\end{array}$ \\
\hline $\mathrm{I}_{0}$ & $77.07^{d}$ & $8.18^{\mathrm{c}}$ & $2.43^{\mathrm{c}}$ & $1.42^{\mathrm{a}}$ & $6.77^{\mathrm{d}}$ & 13.88 & $26.21^{d}$ & $3.97^{\mathrm{a}}$ & 32.97 & $1.77^{\mathrm{c}}$ & $2.99^{\mathrm{c}}$ & $4.78^{\mathrm{C}}$ & $37.06^{\mathrm{c}}$ \\
\hline $\mathrm{I}_{1}$ & $82.33^{\mathrm{a}}$ & $8.99^{\mathrm{a}}$ & $3.31^{a}$ & $0.61^{d}$ & $8.37^{\mathrm{a}}$ & 15.70 & $31.90^{\mathrm{a}}$ & $2.67^{d}$ & 33.45 & $3.30^{\mathrm{a}}$ & $4.09^{a}$ & $7.39^{\mathrm{a}}$ & $44.67^{\mathrm{a}}$ \\
\hline $\mathrm{I}_{2}$ & $80.93^{b}$ & $9.07^{\mathrm{a}}$ & $3.22^{\mathrm{a}}$ & $0.97^{\mathrm{c}}$ & $8.10^{\mathrm{b}}$ & 15.14 & $28.54^{b}$ & $2.87^{\mathrm{C}}$ & 33.17 & $2.94^{\mathrm{b}}$ & $3.74^{b}$ & $6.76^{\mathrm{b}}$ & $43.37^{\mathrm{a}}$ \\
\hline $\mathrm{I}_{3}$ & $79.71^{\mathrm{c}}$ & $8.62^{b}$ & $2.69^{b}$ & $1.20^{\mathrm{b}}$ & $7.42^{c}$ & 13.77 & $27.45^{c}$ & $3.29^{\mathrm{b}}$ & 33.15 & $1.90^{c}$ & $3.00^{c}$ & $4.90^{\mathrm{C}}$ & $38.69^{b}$ \\
\hline Level of significance & ** & ** & ** & ** & ** & NS & ** & ** & NS & ** & ** & ** & ** \\
\hline $\mathrm{s} \bar{x}$ & 0.28 & 0.07 & 0.06 & 0.04 & 0.08 & 0.45 & 1.341 & 0.05 & 0.28 & 0.04 & 0.03 & 0.87 & 0.43 \\
\hline$C V(\%)$ & 3.71 & 6.28 & 6.50 & 11.97 & 4.65 & 4.22 & 4.18 & 10.62 & 1.54 & 4.39 & 3.88 & 4.94 & 2.47 \\
\hline
\end{tabular}

In a column figures having common letter(s) do not differ significant as per DMRT. ** indicates $1 \%$ level of probability, ${ }^{\text {NS }}$ indicates not significant $\mathrm{I}_{0}=$ no irrigation i.e. control

$\mathrm{I}_{1}=$ one irrigation given at Crown Root Initiation (CRI) stage

$\mathrm{I}_{2}=$ two irrigation given at CRI and panicle initiation stages

$\mathrm{I}_{3}=$ three irrigation given at CRI, panicle initiation and grain filling stages. 
Table 3. Interaction effect of seed rate and irrigation on the yield and yield performance of wheat cv. Gourab

\begin{tabular}{|c|c|c|c|c|c|c|c|c|c|c|c|c|c|}
\hline $\begin{array}{l}\text { Interaction (Seed } \\
\text { rate } \times \text { Irrigation) }\end{array}$ & $\begin{array}{l}\text { Plant } \\
\text { height } \\
\text { (cm) }\end{array}$ & $\begin{array}{l}\text { Total } \\
\text { tillers } \\
\text { plant }^{-1}\end{array}$ & $\begin{array}{l}\text { Effective } \\
\text { tillers } \\
\text { plant }^{-1} \\
\text { (no.) }\end{array}$ & $\begin{array}{c}\text { Non-effective } \\
\text { tillers plant } \\
\text { (no.) }\end{array}$ & $\begin{array}{l}\text { Spike } \\
\text { length } \\
(\mathrm{cm})\end{array}$ & \begin{tabular}{|c|} 
Spikelets \\
spike $^{-1}$ \\
(no.)
\end{tabular} & $\begin{array}{c}\text { Filled } \\
\text { grains } \\
\text { Spike }^{-1} \\
\text { (no.) }\end{array}$ & $\begin{array}{l}\text { Unfilled } \\
\text { grains } \\
\text { Spike }^{-1} \\
\text { (no.) }\end{array}$ & $\begin{array}{l}1000- \\
\text { grain } \\
\text { weight } \\
(\mathrm{g})\end{array}$ & $\begin{array}{l}\text { Grain } \\
\text { Yield } \\
\left(\mathrm{t} \mathrm{ha}^{-1}\right)\end{array}$ & $\begin{array}{l}\text { Straw } \\
\text { Yield } \\
\left(\mathrm{t} \mathrm{ha}^{-1}\right)\end{array}$ & $\begin{array}{l}\text { Biological } \\
\text { Yield } \\
\left(\mathrm{t} \mathrm{ha}^{-1}\right)\end{array}$ & $\begin{array}{c}\text { Harvest } \\
\text { Index } \\
(\%)\end{array}$ \\
\hline $\mathrm{S}_{1} \mathrm{I}_{0}$ & 74.50 & $7.75^{\mathrm{d}}$ & $2.00^{\mathrm{j}}$ & $1.50^{\mathrm{a}}$ & $6.25^{\mathrm{g}}$ & 13.15 & $25.00^{i}$ & $4.36^{a}$ & 33.30 & $1.55^{\prime}$ & $2.90^{\mathrm{h}}$ & $4.45^{g}$ & $34.83^{i}$ \\
\hline $\mathrm{S}_{1} \mathrm{I}_{1}$ & 80.23 & $8.88^{\mathrm{ab}}$ & $3.00^{\text {def }}$ & $0.77^{\text {gh }}$ & $8.11^{\mathrm{abc}}$ & 15.00 & $29.20^{\text {def }}$ & $3.00^{\text {efg }}$ & 33.58 & $2.85^{\mathrm{e}}$ & $3.68^{\text {def }}$ & $6.53^{\mathrm{cd}}$ & $43.64^{\mathrm{abc}}$ \\
\hline $\mathrm{S}_{1} \mathrm{I}_{2}$ & 78.89 & $8.95^{\mathrm{ab}}$ & $2.60^{g h}$ & $1.10^{\mathrm{de}}$ & $7.85^{\mathrm{bcd}}$ & 14.25 & $26.40^{\mathrm{hi}}$ & $3.12^{\mathrm{def}}$ & 32.32 & $2.55^{f}$ & $3.50^{\text {efg }}$ & $6.05^{d}$ & $42.15^{\mathrm{cd}}$ \\
\hline $\mathrm{S}_{1} \mathrm{I}_{3}$ & 77.58 & $7.50^{d}$ & $2.30^{i}$ & $1.30^{c}$ & $6.20^{9}$ & 13.00 & $25.60^{\mathrm{hi}}$ & $3.56^{c}$ & 32.44 & $1.65^{\mathrm{kl}}$ & $2.95^{\mathrm{h}}$ & $4.60^{g}$ & $35.87^{\mathrm{hi}}$ \\
\hline $\mathrm{S}_{2} \mathrm{I}_{0}$ & 77.50 & $8.40^{\mathrm{bc}}$ & $2.50^{\mathrm{hi}}$ & $1.40^{\mathrm{b}}$ & $7.00^{\mathrm{ef}}$ & 14.00 & $26.55^{\text {gh }}$ & $4.03^{b}$ & 31.67 & $1.83^{\mathrm{ij}}$ & $2.99^{\mathrm{h}}$ & $4.82^{\mathrm{fg}}$ & $37.97^{\mathrm{fgh}}$ \\
\hline $\mathrm{S}_{2} \mathrm{I}_{1}$ & 82.58 & $9.03^{\mathrm{ab}}$ & $3.46^{\mathrm{bc}}$ & $0.53^{i}$ & $8.50^{\mathrm{ab}}$ & 15.92 & $32.56^{\mathrm{b}}$ & $2.51^{i j}$ & 33.37 & $3.55^{\mathrm{b}}$ & $4.50^{\mathrm{a}}$ & $8.05^{a}$ & $44.10^{\mathrm{abc}}$ \\
\hline $\mathrm{S}_{2} \mathrm{I}_{2}$ & 81.10 & $9.03^{\mathrm{ab}}$ & $3.17^{\mathrm{de}}$ & $0.93^{f}$ & $8.10^{\mathrm{abc}}$ & 15.50 & $28.50^{\mathrm{ef}}$ & $2.60^{\mathrm{hi}}$ & 33.45 & $3.00^{d}$ & $3.90^{\mathrm{cd}}$ & $6.90^{c}$ & $43.48^{\mathrm{bc}}$ \\
\hline $\mathrm{S}_{2} \mathrm{I}_{3}$ & 80.50 & $8.90^{\mathrm{ab}}$ & $2.80^{\mathrm{fg}}$ & $1.10^{\mathrm{e}}$ & $7.80^{\mathrm{cd}}$ & 13.77 & $28.21^{\text {ef }}$ & $3.25^{\text {cde }}$ & 33.13 & $1.90^{\mathrm{hi}}$ & $2.90^{\mathrm{h}}$ & $4.80^{\mathrm{fg}}$ & $39.58^{\mathrm{ef}}$ \\
\hline $\mathrm{S}_{3} \mathrm{I}_{0}$ & 79.67 & $8.55^{\mathrm{abc}}$ & $2.95^{\mathrm{ef}}$ & $1.30^{\mathrm{c}}$ & $7.25^{\mathrm{de}}$ & 14.79 & $28.00^{\mathrm{ef}}$ & $3.25^{\text {cde }}$ & 33.95 & $2.00^{h}$ & $3.20^{g h}$ & $5.20^{\mathrm{ef}}$ & $38.46^{\text {efg }}$ \\
\hline $\mathrm{S}_{3} \mathrm{I}_{1}$ & 85.27 & $9.10^{\mathrm{a}}$ & $3.63^{b}$ & $0.47^{i}$ & $8.63^{a}$ & 16.47 & $35.36^{a}$ & $2.25^{j}$ & 33.22 & $3.70^{\mathrm{a}}$ & $4.36^{\mathrm{ab}}$ & $8.06^{a}$ & $45.91^{a}$ \\
\hline $\mathrm{S}_{3} \mathrm{I}_{2}$ & 83.25 & $9.18^{a}$ & $4.12^{a}$ & $0.83^{9}$ & $8.35^{a b c}$ & 15.90 & $31.33^{\mathrm{bc}}$ & $2.76^{\text {ghi }}$ & 33.24 & $3.36^{c}$ & $4.11^{\mathrm{bc}}$ & $7.47^{b}$ & $44.98^{\mathrm{ab}}$ \\
\hline $\mathrm{S}_{3} \mathrm{I}_{3}$ & 81.25 & $9.15^{a}$ & $3.25^{\mathrm{cd}}$ & $1.20^{\mathrm{cd}}$ & $7.95^{\mathrm{bc}}$ & 14.83 & $29.50^{\mathrm{de}}$ & $3.00^{\text {efg }}$ & 33.51 & $2.20^{9}$ & $3.25^{\text {gh }}$ & $5.45^{\mathrm{e}}$ & $40.37^{\text {de }}$ \\
\hline $\mathrm{S}_{4} \mathrm{I}_{0}$ & 76.60 & $8.03^{\mathrm{cd}}$ & $2.26^{i j}$ & $1.45^{\mathrm{ab}}$ & $6.58^{\mathrm{fg}}$ & 13.58 & $25.30^{\mathrm{hi}}$ & $4.25^{\mathrm{ab}}$ & 32.94 & $1.70^{\mathrm{jk}}$ & $2.90^{\mathrm{h}}$ & $4.60^{g}$ & $36.96^{\mathrm{gh}}$ \\
\hline $\mathrm{S}_{4} \mathrm{I}_{1}$ & 81.25 & $8.93^{\mathrm{ab}}$ & $3.15^{\mathrm{de}}$ & $0.68^{h}$ & $8.25^{\mathrm{abc}}$ & 15.40 & $30.50^{\mathrm{cd}}$ & $2.90^{\mathrm{fgh}}$ & 33.64 & $3.11^{d}$ & $3.80^{\text {cde }}$ & $6.91^{c}$ & $45.01^{\mathrm{ab}}$ \\
\hline $\mathrm{S}_{4} \mathrm{I}_{2}$ & 80.50 & $9.13^{\mathrm{a}}$ & $3.00^{\text {def }}$ & $1.03^{\mathrm{e}}$ & $8.10^{\mathrm{abc}}$ & 14.90 & $27.92^{\mathrm{fg}}$ & $3.00^{\text {efg }}$ & 33.69 & $2.85^{\mathrm{e}}$ & $3.47^{\mathrm{fg}}$ & $6.64^{c}$ & $42.86^{\mathrm{bc}}$ \\
\hline $\mathrm{S}_{4} \mathrm{I}_{3}$ & 79.50 & $8.93^{\mathrm{ab}}$ & $2.43^{\mathrm{hi}}$ & $1.20^{d}$ & $7.73^{\mathrm{cd}}$ & 13.50 & $26.50^{\text {ghi }}$ & $3.36^{\mathrm{cd}}$ & 33.53 & $1.85^{i}$ & $2.90^{\mathrm{h}}$ & $4.75^{\mathrm{fg}}$ & $38.95^{\mathrm{efg}}$ \\
\hline $\mathrm{S}_{1} \mathrm{I}_{0}$ & 74.50 & $7.75^{d}$ & $2.00^{j}$ & $1.50^{\mathrm{a}}$ & $6.25^{9}$ & 13.15 & $25.00^{i}$ & $4.36^{\mathrm{a}}$ & 33.30 & $1.55^{1}$ & $2.90^{\mathrm{h}}$ & $4.45^{9}$ & $34.83^{i}$ \\
\hline Level of significance & NS & * & ** & * & * & NS & * & * & NS & ** & * & * & ** \\
\hline $\mathrm{s} \bar{x}$ & 0.66 & 0.20 & 0.09 & 0.03 & 0.19 & 0.42 & 0.654 & 0.11 & 0.53 & 0.04 & 0.11 & 0.18 & 0.73 \\
\hline CV (\%) & 3.71 & 6.28 & 6.50 & 11.97 & 4.65 & 4.22 & 4.18 & 10.62 & 1.54 & 4.39 & 3.88 & 4.94 & 2.47 \\
\hline
\end{tabular}

In a column figures having common letter(s) do not differ significant as per DMRT

** $=$ indicates $1 \%$ level of probability, ${ }^{*}=$ indicates $5 \%$ level of probability, NS = indicates not significant.

$\mathrm{S}_{1}=100 \mathrm{~kg} \mathrm{ha}^{-1} \quad \mathrm{I}_{\mathrm{o}}=$ no irrigation i.e. control

$\mathrm{S}_{2}=120 \mathrm{~kg} \mathrm{ha}^{-1} \quad \mathrm{I}_{1}=$ one irrigation given at Crown Root Initiation (CRI) stage

$\mathrm{S}_{3}=140 \mathrm{~kg} \mathrm{ha}^{-1} \quad \mathrm{I}_{2}=$ two irrigation given at CRI and panicle initiation stages

$\mathrm{S}_{4}=160 \mathrm{~kg} \mathrm{ha}^{-1} \quad \mathrm{I}_{3}=$ three irrigation given at CRI, panicle initiation and grain filling 
The highest number of total tillers plant $^{-1}$ (9.18) was recorded from the seed rate of $140 \mathrm{~kg} \mathrm{ha}^{-1}$ combined with two irrigations applied at $\mathrm{CRI}$ and panicle initiation stages which was statistically similar with the seed rate of $160 \mathrm{~kg} \mathrm{ha}^{-1}$ and two irrigations applied at CRI and panicle initiation stages and for the seed rate of $140 \mathrm{~kg} \mathrm{ha}^{-1}$ and one irrigation applied at CRI stage. The lowest number of total tillers plant ${ }^{-1}$ was found from the seed rate of $100 \mathrm{~kg} \mathrm{ha}^{-1}$ combined with three irrigations applied at CRI, panicle initiation and grain filling stages. The highest number of effective tillers plant ${ }^{-1}(4.12)$ was found in the seed rate of $140 \mathrm{~kg} \mathrm{ha}^{-1}$ combined with two irrigation applied at CRI and panicle initiation stages and the lowest number of effective tillers plant $^{-1}(2.00)$ was observed from the seed rate of $100 \mathrm{~kg} \mathrm{ha}^{-1}$ and no irrigation applied. The highest number of non-effective tillers plant $^{-1}(1.50)$ was found from the seed rate of $100 \mathrm{~kg} \mathrm{ha}^{-1}$ and with no irrigation applied and the lowest number of non-effective tillers plant ${ }^{-1}$ was counted from the seed rate of $140 \mathrm{~kg} \mathrm{ha}^{-1}$ and one irrigation applied at CRI stage. The longest spike $(8.63 \mathrm{~cm})$ was obtained from the seed rate of $140 \mathrm{~kg} \mathrm{ha}^{-1}$ with one irrigation applied at CRI. The shortest spike was obtained from the seed rate of $100 \mathrm{~kg} \mathrm{ha}^{-1}$ with three irrigations applied at CRI, panicle initiation and grain filling stages. The highest number of filled grains spike $^{-1}$ (35.36) was counted from the use of seed rate of $140 \mathrm{~kg} \mathrm{ha}^{-1}$ and one irrigation applied at CRI stage and the lowest one (25.00) was counted from the seed rate of $100 \mathrm{~kg} \mathrm{ha}^{-1}$ and no irrigation applied. The highest number of unfilled grains spike ${ }^{-1}$ (4.36) was produced by the seed rate of $100 \mathrm{~kg}$ $\mathrm{ha}^{-1}$ and without irrigation and the lowest number of unfilled grains spike ${ }^{-1}(2.25)$ was obtained by the seed rate of $140 \mathrm{~kg} \mathrm{ha}^{-1}$ and one irrigation applied at CRI stage. Among the treatments combination, the highest grain yield $\left(3.70 \mathrm{t} \mathrm{ha}^{-1}\right)$ was found from the seed rate of $140 \mathrm{~kg} \mathrm{ha}^{-1}$ combined with one irrigation applied at CRI stage. The lowest grain yield $\left(1.55 \mathrm{th}^{-1}\right)$ was found from the seed rate of 100 $\mathrm{kg} \mathrm{ha}^{-1}$ and control treatment. The highest straw yield $\left(4.50 \mathrm{t} \mathrm{ha}^{-1}\right)$ was observed from the seed rate of $120 \mathrm{~kg} \mathrm{ha}^{-1}$ combined with one irrigation applied at CRI stage. The lowest straw yield $\left(2.90 \mathrm{t} \mathrm{ha}^{-1}\right)$ was observed from the seed rate of $160 \mathrm{~kg} \mathrm{ha}^{-1}$ combined with three irrigation applied at CRI, panicle initiation and grain filling stages. The highest harvest index (45.91\%) was observed from the seed rate of $140 \mathrm{~kg} \mathrm{ha}^{-1}$ combined with one irrigation applied at CRI stage. The lowest harvest index (34.83\%) was obtained from the use of seed rate of $100 \mathrm{~kg} \mathrm{ha}^{-1}$ with no irrigation applied. From the results of the present study it may, therefore be concluded that the seed rate of $140 \mathrm{~kg} \mathrm{ha}^{-1}$ with one irrigation given at CRI stage may be practiced for better performance of wheat cv. Gourab.

\section{References}

Azimzadeh, M. and Koocheki, A. 1999. Effect of different seed rate and amount of phosphorous fertilizer on yield components of dry land wheat in northern Khorasan. Agril. Sci. and Tech. 13:131-139.

BARI (Bangladesh Agricultural Research Institute). 1990. Means of profitable wheat cultivation, Wheat Research Center, Bangladesh Agril. Res. Inst., Nashipur, Dinajpur. pp.1-11.

BBS (Bangladesh Bureau of Statistics). 2005. Statistical pocket book of Bangladesh. Bangladesh Bureau of Stat. Div., Ministry of Planning, Govt. People's Rep. Bangladesh. P.194.

Gomez, K.A. and Gomez, A.A. 1984. Statistical procedures for Agricultural Research. $2^{\text {nd }}$ edn. John Wiley and Sons. New York. P. 680.

Razzaque, M.A., Suffium, M.A. and Badruddin, M. 1992. Wheat in national economy of Bangladesh. Crop Sci. Proc. First Biennial Conf. CSSB, 18-20 January, 1992: 13-26.

Singh, A. and Singh, O. 1987. Response of late sown wheat to seed rate and nitrogen. Indian J. Agron. 32:290-291.

Singh, V.P.N. and Uttam, S.K. 1993. Performance of wheat cultivars under limited irrigation and fertility management. Indian J. Agron. 38:386-388.

Talukdar, A. S. M. H. M., Sufian A., Dxbury, J.M., Lauren, J.G. and Meinser, C.A. 2004. Effect of tillage options and seed rate on grain yield of wheat. J. Sub trop. Agric. Res. Dev. 2: 57-62.

Thomson, J.A. and Chase, D.L. 1992. Effect of limited irrigation on growth and yield of some-dwarf wheat in Southern New South Wales. Australian Journal of Experimental Agriculture 32:725-730.

Tisdale, S.L., Nelson, W.L. and Beaton, J.D. 1985. Soil fertility and fertilizers Macmillan Publishers, New York. pp: 107-510. 